\title{
Identificação Tomográfica da Bainha Epineural dos Nervos Poplíteos durante Anestesia Regional Intermitente do Pé. Relato de Caso *
}

\section{Tomographic Identification of Popliteal Nerves Epineural Sheath during Foot Intermittent Regional Anesthesia. Case Report}

Karl Otto Geier ${ }^{1}$

\begin{abstract}
RESUMO
Geier KO - Identificação Tomográfica da Bainha Epineural dos Nervos Poplíteos durante Anestesia Regional Intermitente do Pé. Relato de Caso
\end{abstract}

\begin{abstract}
Justificativa e Objetivos - Bloqueios nervosos regionais dos membros inferiores são comumente realizados para procedimentos cirúrgicos e analgesia pós-operatória. O objetivo deste estudo é demonstrar um raro e casual registro tomográfico sobre o posicionamento de cateter na fossa poplítea, originalmente destinado ao nervo ciático, e a dispersão da solução anestésica durante analgesia intermitente num trauma de pé.
\end{abstract}

Relato do Caso - Paciente do sexo masculino, 54 anos, estado físico ASA III, com trauma grave do pé esquerdo foi submetido a bloqueio do nervo ciático através de cateter colocado no ápice do triângulo poplíteo. Como injeções de $10 \mathrm{ml}$ de bupivacaína a 0,375\% com epinefrina a 1:400.000 permitiram curativos e desbridamentos diários com preservação da sensibilidade plantar, o fenômeno foi investigado radiologicamente. Estudos radiográficos e tomográficos contrastados da região poplítea permitiram mostrar o posicionamento do cateter e a dispersão da solução anestésica sob a bainha de cada um dos componentes do nervo ciático.

Conclusões - Os relevantes achados tomográficos contrastados da região poplítea comprovaram recente estudo anatômico sobre a individualização da bainha neural, envolvendo os nervos poplíteos com implicações no desfecho do bloqueio nesta região. A analgesia obtida por cateter mantido na fossa poplítea demonstrou ser efetiva apenas no dermátomo do nervo fibular superficial (dorso medial do pé e hálux).

UNITERMOS - ANALGESIA: Pós-Operatória; TÉCNICAS ANESTÉSICAS, Regional: nervo ciático, nervos poplíteos

\footnotetext{
* Recebido do (Received from) Departamento de Radiologia, Anestesiologia e Serviço de Dor do Hospital Municipal de Pronto Socorro de Porto Alegre, $R S$

1. Anestesiologista do Hospital Municipal de Pronto Socorro, e do Serviço de Dor do Hospital São Lucas da Pontifícia Universidade Católica de Porto Alegre, RS
}

Apresentado (Submitted) em 27 de novembro de 2001

Aceito (Accepted) para publicação em 01 de fevereiro de 2002

Correspondência para (Mail to)

Dr. Karl Otto Geier

Rua Cel. Camisão, 172

90540-050 Porto Alegre, RS

E-mail: carlotto@portoweb.com.br

(C) Sociedade Brasileira de Anestesiologia, 2002

Revista Brasileira de Anestesiologia

Vol. 52, N 5, Setembro - Outubro, 2002

\section{SUMMARY}

Geier KO - Tomographic Identification of Popliteal Nerves Epineural Sheath during Foot Intermittent Regional Anesthesia. Case Report

Background and Objectives - Lower limb regional nervous blocks are common procedures for surgery and postoperative analgesia. This study aimed at describing a rare and casual tomographic image of a catheter in the popliteal fossa, which was originally directed to the sciatic nerve, and of anesthetic solution spread during intermittent analgesia for foot trauma.

Case Report - Male patient, 54 years old, physical status ASA III, with severe left foot trauma and submitted to sciatic nerve block through a catheter inserted in the apex of the popliteal triangle. Since $10 \mathrm{ml}$ injections of $0.375 \%$ bupivacaine with epinephrine 1:400,000 allowed for daily dressings and débridement while preserving plantar sensitivity, the phenomenon was radiologically investigated. Enhanced radiographic and tomographic studies of the popliteal region were able to show catheter positioning and anesthetic spread under the sheath of each component of the sciatic nerve.

Conclusions - Relevant enhanced tomographic findings of the popliteal region have proven a recent anatomic study on the individualization of the neural sheath involving popliteal nerves with implications in blockade outcome. Anesthesia obtained by a catheter in the popliteal fossa was effective only in the superficial fibular nerve dermatome (medial dorsum of foot and hallux).

KEY WORDS - ANALGESIA, Postoperative; ANESTHETIC TECHNIQUES, Regional: sciatic nerve, popliteal nerves

\section{INTRODUÇÃO}

B loqueios nervosos regionais dos membros inferiores são comumente realizados para procedimentos cirúrgicos e analgesia pós-operatória. Anestesia regional do pé, por exemplo, pode ser obtida na fossa poplítea como alternativa às técnicas existentes ${ }^{1-3}$, abordando isoladamente o nervo ciático ${ }^{4,5}$ ou individualmente, cada um de seus dois ramos, o nervo fibular comum e o nervo tibial ${ }^{6}$. Contrariamente ao que ocorre no membro superior, onde o plexo braquial é delimitado por uma bainha fascial em quase toda sua extensão, exceto na região periclavicular ${ }^{7}$, em que a gordura subcutânea e estruturas musculares esboçam a continuidade tuneliforme da bainha, o plexo lombossacro ou parte dele aparentemente não apresenta uma bainha própria, embora esta disposição anatômica tenha sido demonstrada recentemente na região poplítea ${ }^{8,9}$. 
O objetivo deste relato deve-se ao relevante achado tomográfico casual da bainha neural do nervo ciático envolvendo individualmente seus dois ramos poplíteos, nervo tibial e nervo fibular comum ${ }^{10}$ durante anestesia regional periférica intermitente de pé traumatizado.

\section{RELATO DO CASO}

Paciente do sexo masculino, 54 anos, estado físico ASA III, apresentando desenluvamento da face dorsal do pé esquerdo e da face medial do hálux, deu entrada no Hospital de Pronto Socorro onde descartada qualquer fratura, foi encaminhado ao bloco cirúrgico para limpeza e desbridamento da lesão. Apesar da medicação opióide queixava-se de dores contínuas de moderadas a intensas pela Escala Gradual de Dor (sem dor, pouca dor, moderada dor, intensa dor). Após 18 horas de pós-operatório, foi contatado o Serviço de Dor. Ao exame clínico, o pé traumatizado apresentava-se pálido e frio em relação ao pé direito. Decidiu-se pela colocação de um cateter periférico para bloqueio do nervo fibular comum na região poplítea. No bloco cirúrgico, em posição de decúbito ventral, membros estendidos, coxim na face anterior do tornozelo para livre movimentação do pé evocada por um estimulador de nervo periférico, e sob condições estéreis, um cateter Contiplex ${ }^{\circledR}$ (B. Braun) foi introduzido cranialmente 4 a $5 \mathrm{~cm}$ sem obstáculos e aparentemente sem parestesias, no ápice do triângulo poplíteo formado pelos músculos semitendinoso e a porção longa do bíceps femoral de acordo com a abordagem de Singelyn e col. ${ }^{5}$. O cateter foi fixado com curativo transparente e a porção proximal foi posicionada na face anterior da coxa. Extensão, flexão e eversão do pé foram identificados, em conjunto, sob estímulo de 0,4 mA proveniente do Stimuplex ${ }^{\circledR}$ DIG (estimulador de nervo periférico) e definido como adequado posicionamento da agulha. Não se utilizou a dose teste para as contraturas. Filtro antibacteriano foi adaptado ao cateter e $8 \mathrm{ml}$ de bupivacaína a $0,25 \%$ com epinefrina a 1:200.000 foram administrados quando solicitados pelo paciente para analgesia, assim como para repetidas trocas de curativos.

Como a região desenluvada do dorso do pé continuava infectada, necrose residual e minúsculos corpos estranhos foram removidos cirurgicamente dois dias após, sob anestesia regional através do cateter poplíteo, mediante $10 \mathrm{ml}$ de bupivacaína a 0,375\% com epinefrina a 1:400.000. Limpeza e troca de curativos durante os quatro dias seguintes resultaram na boa granulação. No sétimo dia de uso do cateter e sob antibiótico terapia sistêmica, o pé finalmente estava sem infecção (cultura bacteriológica local negativa) e o paciente foi programado para enxerto de pele da lesão. Sob técnica asséptica, um cateter venoso $18 \mathrm{G}, 4,5 \mathrm{~cm}$, foi introduzido no espaço perivascular femoral direito após duas perdas de resistências (fascia lata e fascia ilíaca) de acordo com a abordagem de Winnie e col. e fixado com curativo transparente. Dez ml de bupivacaína a 0,375\% com epinefrina a 1:400.000 injetados pelo cateter poplíteo proporcionaram anestesia do pé e $20 \mathrm{ml}$ de bupivacaína a 0,25\% com epinefrina a 1:200.000 pelo cateter curto perifemoral analgesia per e pós-operatória da área doadora. Todos os procedimentos cirúrgicos foram realizados com adequada hidratação venosa periférica e monitorização com EGC na derivação $D_{\|}$, pressão arterial não invasiva e oximetria de pulso. Tenoxicam cada 12 horas e acetominofen, quando requisitado para dores leves, foram administrados durante três dias. Nenhum sinal de infecção local ou desconforto com os catéteres foi relatado. No quarto dia após a enxertia de pele, os catéteres foram removidos e o paciente deixou o hospital assintomático.

\section{DISCUSSÃo}

Avulsões de pele são caracterizadas pela destruição da microcirculação dérmica e pela presença de minúsculos corpos estranhos, potencialmente infecciosos. Necrose do tegumento dérmico é perceptível durante as primeiras 24 horas.

O pé é inervado pelo nervo ciático com pequena contribuição do nervo safeno interno. No topo do triângulo poplíteo, que tem como base a dobra cutânea intercondileana femoral, como lado medial os músculos semimembranoso e semitendinoso e como lateral a porção longa do bíceps da coxa, o nervo ciático separa-se a partir do plexo lombossacro entre $10 \%{ }^{4}$ e $15 \%{ }^{11}$ dos casos, em dois ramos: o nervo fibular comum com inervação distal, na face dorsal do pé e face medial do hálux; e nervo tibial, responsável pela inervação plantar. Entretanto, na grande maioria das vezes, seus ramos originam-se no ápice do triângulo poplíteo a $10 \mathrm{~cm}$ da dobra cutânea ${ }^{10}$. A abordagem destes nervos com o estimulador de nervo periférico é possível por outra técnica ${ }^{12}$. Por razões práticas e confortáveis, a extremidade proximal do cateter poplíteo foi fixado na face anterior da coxa esquerda. Um cateter venoso $18 \mathrm{G}$ foi colocado no espaço perivascular femoral direito pela técnica da perda de resistência segundo as referências anatômicas superficiais preconizadas por Winnie e col. ${ }^{13}$, objetivando analgesia per e pós-operatória da área doadora de pele da face ântero-lateral da coxa, através de um bloqueio femoral 2 em 1 (territórios do nervo femoral e fêmuro-lateral cutâneo), por ser mais previsível que o bloqueio 3 em 1. Em lugar do estimulador de nervo periférico, utilizamos catéteres curtos do tipo venoso por diferentes técnicas, em bloqueios prolongados que, de acordo com a experiência adquirida $^{14-16}$, e divulgada pela literatura ${ }^{17,18}$, não foram registradas complicações neurológicas ou vasculares.

Originalmente, o procedimento anestesiológico descrito estava sendo destinado à analgesia e anestesia de um pé traumatizado; no entanto, ao se constatar apenas analgesia do dermátomo interessado (dorso do pé e face medial do hálux, inervados pelo nervo fibular superficial) mesmo depois das respostas musculares evocadas pelo estimulador de nervo periférico com nítido envolvimento do nervo ciático, resolveu-se analisar, radiologicamente, o episódio. Os dados clínicos, as imagens radiográficas contrastadas (Figura 1) e as correspondentes imagens tomográficas computadorizadas (Figura 2) confirmaram o posicionamento do cateter no ápice do triângulo poplíteo, onde os dois nervos localizam-se bem próximos entre si, com o nervo fibular comum ligeiramente posterior ao nervo tibial ${ }^{19}$ referendando outros estudos $^{8-10}$. 


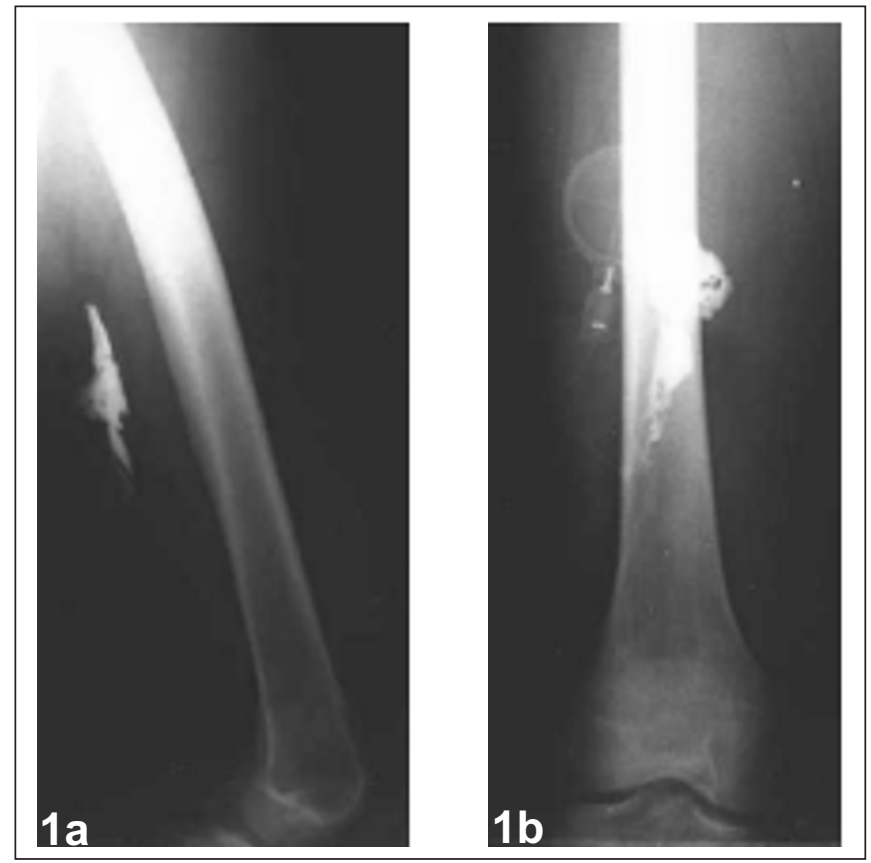

Figura 1 - Imagens Radiográficas Contrastadas do Cateter na Região Poplítea ( $5 \mathrm{ml}$ de contraste)

a) Incidência lateral; b) Incidência ântero-posterior

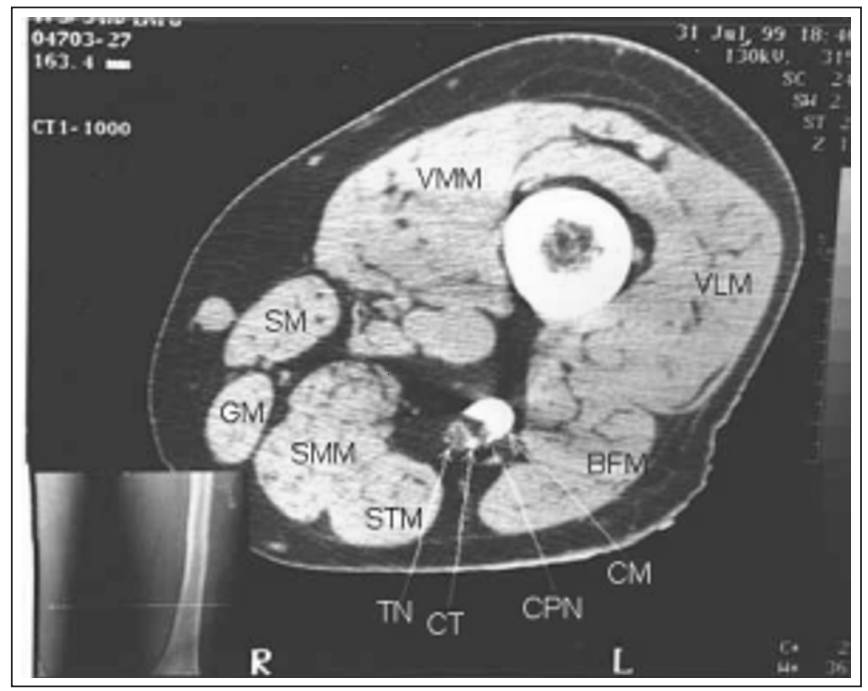

Figura 2 - Imagem de Tomografia Computadorizada Mostrando o Mesmo Cateter (CT) sob a Bainha Epineural do Nervo Tibial (TN) e $5 \mathrm{ml}$ de Contraste (CM) na Distribuição Subepineural do Nervo Fibular Comum (CPN) na Fossa Poplítea

$\mathrm{VMM}=$ músculo vasto medial; $\mathrm{VLM=músculo} \mathrm{vasto} \mathrm{lateral;}$ $\mathrm{SM}=$ músculo sartório; $\mathrm{GM}=$ músculo grácil; $\mathrm{SMM}=$ músculo semimembranoso; STM=músculo semitendinoso; $\mathrm{BFM=múscu-}$ lo bíceps femoral

Recentemente, um estudo anatômico ${ }^{10}$ verificou que o nervo ciático composto pelos nervos tibial e fibular comum, ambos fisicamente unidos mas fisiologicamente independentes, encontra-se envolto por uma bainha. Entretanto, no ápi- ce da região poplítea, esta bainha se individualiza envelopando, separadamente, os nervos tibial e fibular comum ${ }^{10}$. Aconstatação anatômica de Vloka e col. ${ }^{10}$ foi confirmada por casualidade, no presente estudo tomográfico, sendo estas imagens, provavelmente, as primeiras registradas na literatura. De fato, as imagens revelaram o cateter sob o epineuro do nervo tibial e o contraste envolvendo o nervo fibular comum (Figura 2). As respostas motoras evocadas pelo estimulador de nervo periférico não foram individualizadas para cada nervo e, sim, simultaneamente, talvez porque a agulha do conjunto Contiplex ${ }^{\circledR}$ tenha sido posicionada eqüidistante entre os referidos nervos e bem próximo às suas origens. $O$ campo eletromagnético gerado estimulou com a mesma intensidade ambos os nervos, obtendo-se respostas motoras simultâneas e apropriadas aos músculos atingidos (flexão, extensão e inversão do pé) como se o nervo ciático estivesse sendo o alvo da estimulação.

O paciente queixou-se de desconforto durante a introdução do cateter, porém, não foi possível precisar se eram sensações parestésicas. Neste momento, o cateter deve ter penetrado na bainha do nervo tibial e ascendido até a origem do nervo fibular comum ensejando a injeção do anestésico local neste último. Isto foi clinicamente constatado porque o paciente referiu analgesia (insensibilidade dolorosa) no local do trauma, com baixas doses e anestesia com altas doses de anestésico local apenas no território inervado pelo nervo fibular superficial (metade ântero-lateral da perna e dorso medial do pé), enquanto a sensibilidade do território do nervo tibial (região plantar) ficou preservada.

Subjetivamente, o paciente referiu também elevação de temperatura (antes frio, o pé tornou-se aquecido) e de volume na região dorsal do pé enquanto que, objetivamente, exibiu notável hiperemia da lesão desenluvada, em relação ao pé direito, minutos após cada injeção da solução anestésica. Nas referidas imagens (Figura 2) pode-se deduzir que o cateter seguiu o trajeto subepineural do nervo tibial e sua extremidade permitiu injetar o contraste sob o epineuro do nervo fibular comum, reproduzindo os resultados de um estudo anatômico prévio em que se injetou azul de metileno sob a bainha neural ${ }^{8}$. Deve-se enfatizar que o aspecto anatômico observado ${ }^{10}$ pode repercutir sobre o desfecho anestésico nos bloqueios dos nervos poplíteos, como no presente episódio.

Para a analgesia pós-operatória optou-se pelas administrações intermitentes de anestésico local quando requisitadas pelo paciente, prevenindo dosagem excessiva ${ }^{20}$. Sem demonstrações de infecção localizada demonstrado laboratorialmente (cultura bacteriana negativa), a analgesia obtida pelo cateter poplíteo manteve o pé com melhor circulação, tornando-o hiperêmico e quente ambos devido à vasodilatação resultante do bloqueio simpático regional ${ }^{21}$, tomando como referência o pé direito ${ }^{22}$.

Não foram observados deslocamentos do cateter, infecção local (cultura bacteriana negativa) ou dobras de ambos catéteres, embora sinais de inflamação tenham sido notados ao redor de suas emergências dérmicas. Sinais clínicos e radiológicos presenciados no presente estudo foram coinciden- 
tes ao posicionamento final do cateter poplíteo devido às implicações anatômicas desta região.

\section{AGRADECIMENTOS}

O autor agradece ao técnico em Radiologia, Adalberto Pizzio, CRTR 0103, pela inestimável contribuição na obtenção das imagens radiológicas e tomográficas e a Martin Geier pela colaboração na elaboração das figuras do texto.

\section{Tomographic Identification of Popliteal Nerves Epineural Sheath during Foot Intermittent Regional Anesthesia. Case Report}

\author{
Karl Otto Geier, M.D.
}

\section{INTRODUCTION}

Lower limb regional nervous blocks are common procedures for surgery and postoperative analgesia. Foot regional anesthesia, for example, may be obtained in the popliteal fossa as an alternative for existing techniques ${ }^{1-3}$, isolately addressing the sciatic nerve ${ }^{4,5}$ or each of its two branches individually: common fibular nerve and tibial nerve ${ }^{6}$. As opposed to upper limbs, where the brachial plexus is delimited by a fascial sheath in almost all its extension, except for the periclavicular region ${ }^{7}$ where subcutaneous fat and muscle structures outline sheath's tunneling continuity, the lumbosacral plexus, or part of it, apparently seems not to have its own sheath, although such anatomic disposition had been recently shown in the popliteal region ${ }^{8,9}$. This report aimed at describing a relevant and casual tomographic finding of the sciatic nerve neural sheath involving its two popliteal branches individually - tibial nerve and common fibular nerve ${ }^{10}$ - during peripheral intermittent regional anesthesia of a traumatized foot.

\section{CASE REPORT}

Male patient, 54 years old, physical status ASA III with degloving of left foot dorsal face and hallux medial face admitted to an Emergency Hospital where, after ruling out any fracture, he was referred to the surgical center for injury cleaning and debridement. In spite of opioid medication, he complained of continuous moderate to severe pain according to the Pain Gradual Scale (no pain, mild pain, moderate pain, severe pain). After 18 postoperative hours, the Pain Department was called in. At clinical evaluation, the traumatized foot was pale and cold as compared to the right foot. A decision was made to insert a peripheral catheter to block the common fibular nerve in the popliteal region. In the operating center and in the prone position with extended limbs and a pad placed under the ankle for free foot movement evoked by a peripheral nerve stimulator, and under sterile conditions, a Contiplex ${ }^{\circledR}$ catheter (B. Braun) was inserted cephalad 4 to 5 $\mathrm{cm}$, without obstacles and apparent paresthesias, at the popliteal triangle apex (formed by semitendinous muscles and the long portion of the femoral biceps, according to Singelyn et al. ${ }^{5}$ ). The catheter was fixed with a transparent dressing and the proximal portion was positioned on the anterior face of the thigh. Foot extension, flexion and elevation were jointly identified by a $0.4 \mathrm{~mA}$ stimulation coming from the Stimuplex ${ }^{\circledR}$ DIG (peripheral nerve stimulator) and needle positioning was defined as adequate. No contractures test dose was used. An antibacterial filter was adapted to the catheter and $8 \mathrm{ml}$ of $0.25 \%$ bupivacaine with epinephrine $1: 200,000$ were administered at patient's request for analgesia and for repeated dressing replacements.

Since the degloved region of the dorsum of foot remained infected, residual necrosis and minute foreign bodies were surgically removed two days later under regional anesthesia through the popliteal catheter, with $10 \mathrm{ml}$ of $0.375 \%$ bupivacaine with epinephrine 1:400,000. Cleaning and dressing replacements during the next four days resulted in good granulation. After 7 days of catheter insertion and under systemic antibiotic therapy, the foot was finally infection-free (local negative culture) and patient was scheduled for skin grafting. Under aseptic technique, a $4.5 \mathrm{~cm} 18 \mathrm{G}$ intravenous catheter was inserted in the right femoral perivascular space after two losses of resistance (fascia lata and fascia iliaca) according to Winnie et al., and was fixed with a transparent dressing. Foot anesthesia was induced with $10 \mathrm{ml}$ of $0.375 \%$ bupivacaine with epinephrine 1:400,000 injected through the popliteal catheter and peri and postoperative analgesia of the donor area was achieved with $20 \mathrm{ml}$ of $0.25 \%$ bupivacaine with epinephrine 1:200,000 through the short perifemoral catheter. All surgical procedures were performed with adequate peripheral intravenous hydration and ECG monitoring at $D_{\|}$, non-invasive blood pressure and pulse oximetry. Tenoxicam at 12-hour periods and acetominofen, when requested for mild pain, were administered for three days. No local infection or catheter discomfort was reported. Four days after skin grafting catheters were removed and patient was discharged without symptoms.

\section{DISCUSSION}

Skin avulsions are characterized by dermal microcirculation destruction and by the presence of minute and potentially infectious foreign bodies. Dermal tegument necrosis is noticed during the first 24 hours.

The foot is innervated by the sciatic nerve with a minor contribution of the internal saphenous nerve. At the top of the popliteal triangle, which has the femoral intercondylar skin fold as its base, the semimembranous and semitendinous muscles as the medial side and the long portion of the femoral 
biceps as the lateral side; the sciatic nerve is divided early from the lumbosacral plexus, in $10 \%{ }^{4}$ to $15 \%{ }^{11}$ of the cases, in two branches: common fibular nerve with distal innervation in the foot dorsal face and hallux medial face, and tibial nerve, responsible for plantar innervation. However, most of the times, its branches originate in the popliteal triangle apex at $10 \mathrm{~cm}$ of the skin fold ${ }^{10}$. The approach of such nerves with the peripheral nerve stimulator is enabled by a different technique ${ }^{12}$. For practical and comfortable reasons, the proximal edge of the popliteal catheter was fixed on the anterior face of the left thigh. An $18 \mathrm{G}$ intravenous catheter was inserted in the right femoral perivascular space using the loss of resistance to air technique according to superficial anatomic references preconized by Winnie et al. ${ }^{13}$, aiming at peri and postoperative analgesia of the skin donor area located on the femoral anterolateral face, through a 2 in 1 femoral blockade (femoral nerve and lateral cutaneous nerve of thigh), for being more predictable than the 3 in 1 blockade. Instead of a peripheral nerve stimulator, we used short intravenous catheters by different techniques, in prolonged blockades which, according to the experience ${ }^{14-16}$ and the literature ${ }^{17,18}$, do not lead to neurological or vascular complications.

Originally, the above mentioned anesthetic procedure was aimed only at analgesia and anesthesia of a traumatized foot; however, after confirming analgesia only in the involved dermatome (dorsum of foot and medial face of hallux, innervated by the superficial fibular nerve) even after muscle responses evoked by peripheral nerve stimulator with clear sciatic nerve involvement, we decided to radiologically study the event. Clinical data, enhanced radiographic images (Figure 1) and corresponding tomographic images (Figure 2) have confirmed the catheter positioning in the popliteal triangle apex where both nerves are very close to each other, with the common fibular nerve slightly posterior to the tibial nerve ${ }^{19}$ and confirming other studies ${ }^{8-10}$.

A recent anatomic study ${ }^{10}$ has observed that the sciatic nerve, composed by the tibial and the common fibular nerves, both physically joined but physiologically independent, is involved by a sheath. However, in the popliteal apex, this sheath is individualized, separately involving the tibial nerve and the common fibular nerve ${ }^{10}$.

The anatomic observation by Vloka et al. ${ }^{10}$ was casually confirmed by our tomographic study and these may probably be the first images published in the literature. In fact, the images revealed a catheter under the tibial nerve epineuron and the contrast involving the common fibular nerve (Figure 2). Motor responses evoked by the peripheral nerve stimulator were not individualized for each nerve but rather simultaneous, because the Contiplex ${ }^{\circledR}$ needle was positioned equidistant from the referred nerves and very close to their origins. The generated electromagnetic field has stimulated both nerves with the same intensity, obtaining simultaneous and adequate motor responses to the affected muscles (foot flexion, extension and eversion) as if the sciatic nerve were the stimulation target.

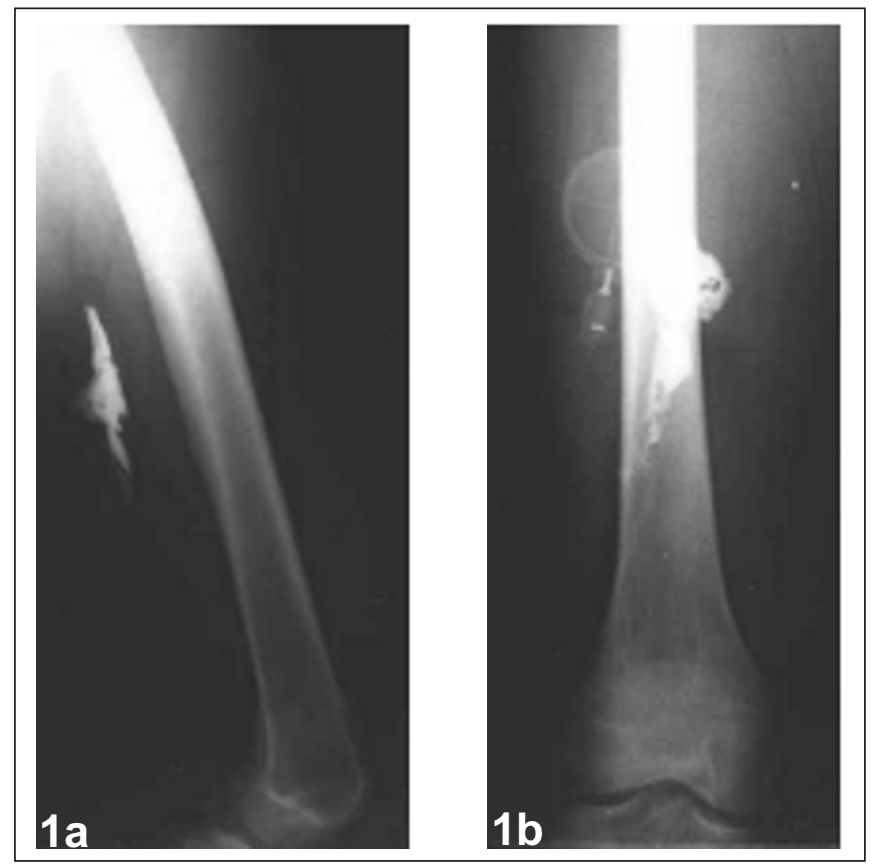

Figure 1 - Radiographic Images from the Catheter with $5 \mathrm{ml}$ of $\mathrm{CM}$ in the Popliteal Fossa

a) Lateral view; b) Posteroanterior view

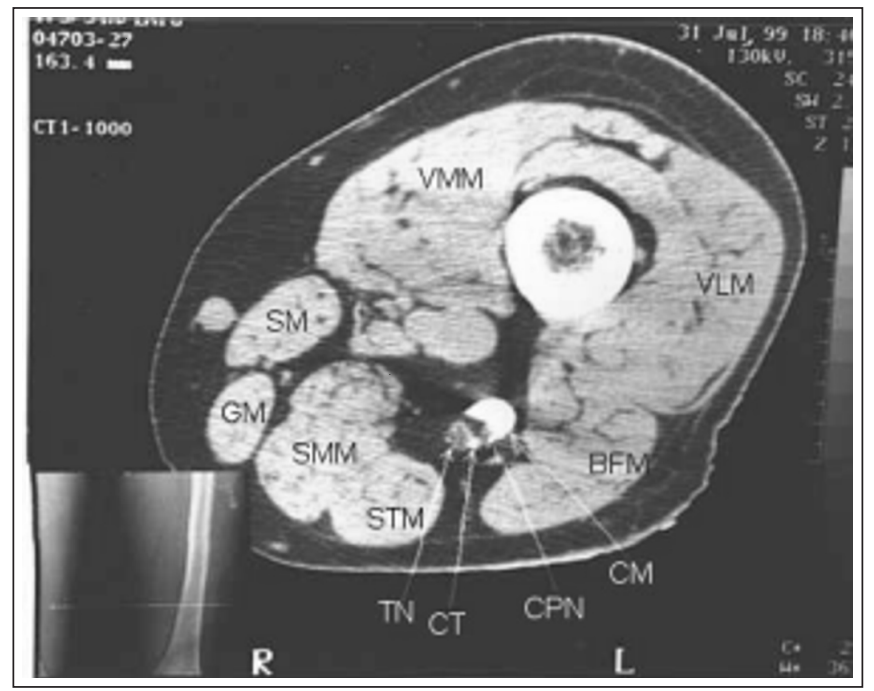

Figure 2 - Tomographic Image Showing the Same Catheter (CT) Under the Tibial Nerve Epineural Sheath (TN) and $5 \mathrm{ml}$ Contrast (CM) in the Popliteal Fossa.

MVM=Musculus Vastus Medialies; MVL=Musculus Vastus Lateralis: $M S=$ Musculus Sartorius: $G M=G$ racilis Muscle; SMM=Semimembranous muscle; STM=Semitendinous Muscle; BMT=Biceps Muscle of Thigh

Patient referred discomfort during catheter insertion but it was not possible to determine whether those were paresthetic sensations. At that moment, the catheter must have crossed the tibial nerve sheath and ascended to the origin of the common fibular nerve where the local anesthetic solution was injected. This was clinically confirmed because patient referred analgesia (pain insensitivity) at trauma site, 
with low anesthetic doses and anesthesia with high local anesthetic doses only in the territory innervated by the superficial fibular nerve (anterolateral half of leg and medial dorsum of foot), while tibial nerve territory sensitivity (plantar region) was preserved.

Patient has also subjectively referred increase in temperature (initially cold, the foot became warm) and volume at foot dorsal face, while objectively presenting an incredible hyperemia of the degloved region as compared to the right foot, minutes after each anesthetic injection.

From our images (Figure 2) one may conclude that the catheter followed the tibial nerve subepineural pathway and its edge allowed for the contrast to be injected under the common fibular nerve epineuron, reproducing the results of a previous anatomic study where methyl blue was injected under the neural sheath ${ }^{8}$. It must be emphasized that the observed anatomic aspect ${ }^{10}$ may affect popliteal nerve anesthetic blockade outcome, such as in our case.

Postoperative analgesia was obtained with intermittent local anesthetic administrations, when requested, to prevent overdose ${ }^{20}$. Without signs of localized infection under lab tests (negative bacterial culture), popliteal catheter analgesia improved foot circulation, making it hyperemic and warm, both due to vasodilation resulting from regional sympathetic block $^{21}$, as compared to the right foot ${ }^{22}$.

There were no catheter displacement, local infection (negative bacterial culture) or catheter bending, in spite of inflammation signs noticed around the skin hole. Clinical and radiological findings in this study were in line with the final popliteal catheter positioning due to anatomic implications of this region.

\section{ACKNOWLEDGEMENT}

The author acknowledges Radiology technician, Adalberto Pizzio, CRTR 0103, for his invaluable contribution in obtaining radiological and tomographic images, and to Martin Geier for his cooperation in preparing the figures from the text.

\section{REFERÊNCIAS - REFERENCES}

01. Pauchet V - Anestesia Regional. Rio de Janeiro. Guanabara Koogan, 1923;198-202.

02. Mansour NY - Reevaluating the sciatic nerve block: Another landmark for consideration. Reg Anesth, 1993;18:322-323.

03. Löfström B - Bloqueo de los Nervios Periféricos de la Pierna a Nível del Tobillo, em: Eriksson E - Manual llustrado de Anestesia Local. Copenhagen/Dinamarca, 1969;108-111.

04. Rorie DK, Byer DE, Nelson DO et al - Assessment of block of the sciatic nerve in the popliteal fossa. Anesth Analg, 1980;59: 371-376.

05. Singelyn FJ, Gouverneur JM, Gribomont BF - Popliteal sciatic nerve block aided by a nerve stimulator: a reliable technique for foot and ankle surgery. Reg Anesth, 1991;16:278-2815.
06. Paqueron X, Bouaziz H, Macalou D et al - The lateral approach to the sciatic nerve at the popliteal fossa: one or two injections? Anesth Analg, 1999;89:1221-1225.

07. Cornish PB, Greenfield LJ - Brachial Plexus Anatomy. Reg Anesth, 1997;22:106-107

08. Vloka JD, Hadzic A, Lesser JB et al -.Common epineural sheath for the nerves in the popliteal fossa and its possible implications for sciatic nerve block. Anesth Analg, 1997;84:387-390.

09. Zetlaoui PJ, Bouaziz H - Lateral approach to the sciatic nerve in the popliteal fossa. Anesth Analg, 1998;87:79-82.

10. Vloka JD, Hadzic A, April E et al - The division of the sciatic nerve in the popliteal fossa: anatomical implications for popliteal nerve blockade. Anesth Analg, 2001;92:215-217.

11. Spalteholz W - Atlas de Anatomia Humana. Barcelona. Editorial Labor. $3^{a}$ Ed, 1967;890.

12. Singelyn FJ, Aye F, Gouverneur JM - Continuous popliteal sciatic nerve block: an original technique to provide postoperative analgesia after foot surgery. Anesth Analg, 1997;84:363-386.

13. Winnie AP, Ramamurthy $S$, Durrani $Z$ - The inguinal paravascular technique of lumbar plexus anesthesia: the "3:1 block". Anesth Analg, 1973;52:989-996.

14. Geier KO - Bloqueio do plexo braquial no trauma: analgesia regional prolongada por cateter axilar. Rev Bras Anestesiol, 1995;45:173-182.

15. Geier KO, Rocha VHB - Bloqueio contínuo do plexo lombar via compartimento ilíaco, combinado com bloqueio contínuo do nervo femoral em trauma grave de membro inferior. Relato de caso. Rev Bras Anestesiol, 2001;51(1): 53-58.

16. Geier KO - Analgesia regional prolongada com catéteres periféricos. Relato de casos. Rev Bras Anestesiol, 2002:52: 35-46.

17. Lynch J, Trojan S, Arhhelger S et al - Intermittent femoral nerve blockade for anterior cruciate ligament repair. Use of a catheter technique in 208 patients. Acta Anaesthesiol Belg, 1991;42: 207-212.

18. Sarma VJ - Long-term continuous axillary plexus blockade using $0.25 \%$ bupivacaine. Acta Anaesthesiol Scand, 1990;34: 391-393.

19. Vloka JD, Hadzic A, Singson R - The lateral approach to popliteal nerve block. double injection technique revisited. Anesthesiology, 1999;V91:3A:A883.

20. Mezzatesta JP, Scott DA, Schweitzer AS et al - Continuous axillary brachial plexus block for postoperative pain relief. Reg Anesth, 1997;22:357-362.

21. Bonica JJ - Sympathetic and Somatic Segmental and Peripheral Nerve Supply to the Hips and Lower Limbs, em: Bonica JJ - The Management of Pain. $2^{\text {nd }} E d$, Philadelphia: Lea\&Febiger, 1990;1421-1423.

22. Lehtipalo S, Winso O, Koskinen L-OD et al - Cutaneous sympathetic vasoconstrictor reflexes for the evaluation of interscalene brachial plexus block. Acta Anaesthesiol Scand, 2000;44: 946-952.

\section{RESUMEN}

Geier KO - Identificación Tomográfica de la Vaina Epineural de los Nervios Poplíteos durante Anestesia Regional Intermitente del Pie. Relato de Caso

Justificativa y Objetivos - Bloqueos nerviosos regionales de los miembros inferiores son comúnmente realizados para procedimientos quirúrgicos y analgesia pós-operatoria. El objetivo de este estudio es demostrar un raro y casual registro

Revista Brasileira de Anestesiologia Vol. 52, № 5 , Setembro - Outubro, 2002 
tomográfico sobre la posición del catéter en la fosa poplítea, originalmente destinado al nervio ciático, y la dispersión de la solución anestésica durante analgesia intermitente en un trauma de pie.

Relato de Caso - Paciente del sexo masculino, 54 años, estado físico ASA III, con trauma grave del pie izquierdo fue sometido a bloqueo del nervio ciático a través de catéter colocado en el ápice del triángulo poplíteo. Como inyecciones de $10 \mathrm{ml}$ de bupivacaína a 0,375\% con epinefrina a 1:400.000 permitieron curativos y desbridamientos diarios con preservación de la sensibilidad plantar, el fenómeno fue investigado radiológicamente. Estudios radiográficos y tomográficos contrastados de la región poplítea permitieron mostrar la posición del catéter y la dispersión de la solución anestésica bajo la vaina de cada uno de los componentes del nervio ciático.

Conclusiones - Los relevantes hallados tomográficos contrastados de la región poplítea comprobaron reciente estudio anatómico sobre la individualización de la vaina neural envolviendo los nervios poplíteos con implicaciones en el resultado del bloqueo En esta región. la analgesia obtenida por catéter mantenido en la fosa poplítea demostró ser efectiva apenas en el dermátomo del nervio fibular superficial (dorso medial del pie y hálux). 